\title{
Murabaha Dispute Settlement In A Sharia Rural Bank (BPRS) Of Klaten
}

\author{
Rifanatus Sarah Dzatihanani ${ }^{1}$ and Imron Rosyadi ${ }^{2}$, \\ ${ }^{1}$ Faculty of Islamic Studies, Universitas Muhammadiyah \\ Surakarta \\ email: rifanatussarah7@gmail.com \\ ${ }^{2}$ Faculty of Islamic Studies, Universitas Muhammadiyah \\ Surakarta \\ email: Imron.Rosyadi@ums.ac.id
}

\begin{abstract}
In August 2018 the Religious Court accepted the Sharia Rural Bank Al-Mabrur, located in the city of Klaten, application as plaintiff under number 1135 / Pdt.G / 2018 / PA / Klt. They sued Tri Suyatmi and Panut Basuki, for their violation of disobeying the Murabaha contract number: 2414 / APJBM / AL MABRUR / $\mathrm{VI} / 2017$. Based on the case above, a review of decision number 1135 / Pdt.g / 2018 / PA.Klt will be examined. In this article, we will review first of all, what is the basis for the consideration of the Klaten Religious Court judges in completing case number 1135 / Pdt.g / 2018 / PA.Klt. Secondly, Is the Religious Court judge's decision regarding the Murabaha contract in the Sharia Rural Bank Al-Mabrur in accordance with the DSN-MUI Fatwa? This research is a type of qualitative research, which uses an evaluative method that is by measuring certain benefits and activities, as well as collecting and analyzing data systematically to determine the value or benefits of the contents of decision file number 1135 / Pdt.g / 2018 / PA.Klt. The data were obtained from observations, interviews with Judges and Clerks of the Klaten Religious Court, and documents in the Religious Courts. Based on the results of the study it can be concluded that: 1) Judge's decision on case number 1135 / Pdt.g / 2018 / PA.Klt is to declare legal Murabaha contract number 2414 / APJBM / AL MABRUR / VI / 2017, 2) Defendant is proven to have defaulted and must
\end{abstract}


pay material compensation of Rp. 36,269,864 and pay the costs of the case, 3) The legal basis used by the Panel of Judges in setting decisions is in accordance with Islamic Economic Law, namely using the Fatwa of the Sharia Council of the Indonesian Ulema Council (DSN-MUI) concerning the Murabaha contract.

Keywords: Murabaha, Tort, Fatwa DSN-MUI, The Courts.

\section{INTRODUCTION}

Conflicts and disputes that occur in Islamic banking are increasing in their types, all of which are in need of solutions and sttelement. One of the cases that occurred was a dispute at the BPRS Al-Mabrur in a murabaha contract. Tri Suyatmi, in this matter, acts for and on behalf of himself who has received the approval of her husband, Panut Basuki, hereinafter referred to as the customer. The customer has submitted an application to the BPRS Al Mabrur to purchase land, and based on the customer's request the BPRS Al Mabrur agrees, and with this murabaha agreement, binds itself to finance the entire purchase price, provides and then sells the land to the customer in accordance with the existing provisions of the murabaha contract. Then the two parties agreed to make and sign this murabaha contract.

Then the Customer violates the terms, or in other words, breaks promises to the agreed murabaha contract. The customer promises to make installment payments in accordance with the established installment schedule. The customer agrees to make payments according to the installment schedule each month until the contract is due. However, in reality the customer does not carry out these obligations. There was a dispute in carrying out this contract, then the customer and the BPRS Al Mabrur tried to settle the meeting. The event that seeks to resolve differences of opinion through deliberation does not bear any fruitthat can be agreed by both parties. The customer and the BPRS Al Mabrur hereby agree to appoint, determine and authorize the Klaten Religious Court office to give its decision, whose legal opinion or the decision determined is of a nature final and binding. 
The Klaten Religious Court on August 1, 2018, in the Registrar's Office, received a lawsuit regarding the fulfillment of the murabaha financing agreement with case number 1135 / Pdt.G / 2018 / PA / Klt filed by the BPRS Al Mabrur, which is domiciled in the Avenue Klaten Highway -Solo Km 04, Kerubaru, Belangwetan. North Klaten, in this case was represented by Arifin Hidayat, SE. In his position as managing director of the BPRS Al Mabrur. Here they sued Tri Suyatmi and Panut Basuki as the sustomer. In the court's decision, the court granted the suit in its entirety, stating that by law, the defendant's act of achievement was breaking the promise to the plaintiff.

\section{LITERATURE REVIEW Previous Studies}

From this study, the authors found several previous researchers who discussed related issues by the author, inter alia:

Eko Mulyono, (An Essay of the Sharia Faculty of IAIN Salatiga University, 2017) in his essay entitled Analisis Terhadap Putusan Hakim Dalam Kasus Sengketa Ekonomi Syariah Di Pengadilan Agama (PA) Purbalingga Tentang Wanprestasi Akad murabaha (Decision no 1720 / pdt.g / 2013 / PA. pbg), states that the legal considerations used by the Panel of Judges in deciding Decision No. 1720 / Pdt.G / 2013 / PA.Pbg is Law Number 7 of 1989 as amended by the first amendment to Law No.3 of 2006 and amended by the second amendment to Law No. 50 of 2009 concerning Religious Courts, Law No. 1 of 1995 concerning Limited Liability Companies, Compilation of Sharia Economic Law (KHES) and Herzien Inlandsch Reglement (HIR). With regard to legal considerations by the judge, the use of Law no. 1 of 1995 concerning Limited Liability Companies is incorrect because the law has been replaced by Law No. 40 of 2007 concerning Limited Liability Companies. While the use of Law No.50 Year 2009 concerning Religious Courts, KHES and HIR as legal considerations by judges is appropriate.

Ilyas Hanafi, (An Essay of the Sharia Faculty of IAIN University Salatiga, 2017) in his essay entitled Analisis Putusan 
Pengadilan Agama Purbalingga Tentang Wanprestasi Akad murābaḥah Studi Kasus Putusan Perkara Number 0311 / pdt.g / 2014 / Pa.Pbg, states that the legal basis used by the Panel of Judges is Law Number 7 of 1989 as amended by Law No. 3 of 2006 and amendments to (2) two of Law No. 50 of 2000 concerning Religious Courts which contains the absolute authority of the Religious Courts Law No. 1 of 1995 as amended by Law No. 40 of 2007 concerning Limited Liability Companies (PT) contains the position of directors in being responsible for the interests of the company as representatives in and outside the Court. The compilation of Sharia Economic Laws contains the Forms established legally in force Nash Sharia. And HIR (Herzien Inlandsch Reglement) contains the Verstek decision and the imposition of court fees.

Ulfa Kharisaturrodiyah, (An Essay of the Sharia Faculty of IAIN Ponorogo University, 2018) in her essay entitled Analisis Hukum Ekonomi Islam Terhadap Putusan Hakim dalam Sengketa Ekonomi Syariah (Studi Putusan Pengadilan Tinggi Agama Yogyakarta Nomor 63/pdt.g/2011/pta.yk), states that the reason for consideration used by the Assembly in determining the decision Number 63 / Pdt.G / 2011 / PTA.Yk is in accordance with Islamic Economic Law, namely the interpretation of law or in terms of Islamic Law called Ijtihad Tatbhiqi in this case the Panel of Judges uses the ijtihad method namely istisläh or Al Masālih Al-Mursalah. While the legal basis used by the Panel of Judges in setting decisions is also in accordance with Islamic Economic Law, namely DSN-MUI Fatwa Number / DSN-MUI / IV / 2000 concerning murabaha financing, Compilation of Sharia Economic Laws (KHES) regarding agreements. In setting the decision, the Panel of Judges also included the legal basis for the Civil Code (KUHP) to strengthen the referral and outcome of the decision.

The researches above are different from the research that will be carried out by the author. Aforementioned essays and previous studies that also discuss the analysis of the judge's decision have some differences from the research conducted by the author, regarding the settlement of murabaha contract disputes in the 
BPRS Al-Mabrur of Klaten (Analysis of the Klaten Religious Court's decision number 1135 / Pdt.g / 2018 / PA.Klt)

\section{Murabaha Contract}

The financing is a form of providing funds or capital goods by not withdrawing funds directly from the community (Sunaryo, 2008). In the narrow sense, financing is used to define funding carried out by financial institutions such as Islamic banks to customers (Muhammad, 2005). There are several forms of sale and purchase agreements and contracts that are often used by Islamic banks in financing their customers, one of which is murabaha.

Therefore, what is meant by murabaha financing is an agreement on the provision of goods based on buying and selling where the bank finances or buys the needs of the customer's goods or investments and resells them to the customer plus the agreed profit. Customer payments are made in installments within the specified time period (Bagya Agung Prabowo, 2012).

\section{The Default}

Defaults come from Dutch, which means poor performance. What is meant by default is a condition caused by negligence or mistake, so the debtor cannot fulfill the achievement as specified in the agreement and not in a compelling condition (Nindyo Pramono, 2008).

Defaults are certainly inseparable from the agreements that are the basis for determining whether or not there is a default. In connection with the form of the content or achievement of the engagement, there are classification of the engagement as follows (1) the obligation to give something, (2) the obligation to do or do something, and (3) the obligation not to do something (Satrio, 1992).

Defaults that are a person's negligence can take four forms, namely: 1) Not doing what he is promised to do, 2) Doing what he promised, but not as promised, 3) Doing what he promised but too late, 4) Doing something according to the agreement do not do it (Subekti, 2002). 


\section{Confiscation Guarantee}

A guarantee seizure (conservatoir-beslag) is a seizure carried out by the court at the request of the plaintiff over someone else's property (ie the defendant's property) so that the plaintiff's rights are guaranteed to be fulfilled by the defendant after the plaintiff is adjudicated to win in his case later (Roihan, A Rasyid, 2007 ).

The application of confiscation is basically restricted only to disputes over debts incurred by defaults. With the seizure put on the property of the defendant to a third party, so that it remains intact until the verdict is legally binding. If the defendant does not fulfill the voluntary payment, the payment of the debt or compensation, is forcibly taken from confiscated goods through auction sales.

Thus, the act of confiscating the property of the defendant is not to be submitted and owned by the plaintiff, but is intended to pay off the defendant's debt payments to the plaintiff (M. Yahya Harahap, 2012). If the claim regarding a dispute is imposed to immovable property, the confiscation of the guarantee is intended to guarantee the integrity and presence of the goods so that they are maintained during the inspection process.

\section{RESEARCH METHODS}

This research is of field research that intends to collect data directly (Supardi, 2005). In this case the object of research is the case number 1135 / Pdt.g / 2018 / PA.Klt. about the murabaha contract in the Religious Courts. The research approach used by the authors in this study is a qualitative approach that is evaluative. The evaluative method aims to measure certain benefits and activities, as well as systematically collect and analyze data to determine the value or benefits of the contents of decision file number 1135 / Pdt.g / 2018 / PA.Klt. about the murabaha contract in the Religious Courts.

\section{Type of Data}

This type of research data refers to primary data and secondary data. Primary data, or first-hand data, is data obtained directly. Secondary data or second hand data is data obtained from other 
parties, not directly obtained by researchers (Saifuddin Azwar, 2007). The primary research, namely, the researcher went directly to the field, dealing directly with a guest speaker of the Klaten Religious Court Judge. While secondary research refers to the contents of the decision file number 1135 / Pdt.g / 2018 / PA.Klt. and other literature relating to the contents of the decision.

\section{Method of collecting data}

Interview is an oral question and answer process, carried out by two or more people dealing physically. Klaten Religious Court acts as one of the parties concerned as the subject of the interviewer's author to obtain valid data information (Sutrisno Hadi, 2007). In this case the researcher is interviewing the judge who closed the case, and the clerk.

Documentation is a data collection technique or searching for the subject of documents. With this method the researcher is expected to get information in the form of decision files and photographs relating to the research subject.

\section{Data analysis technique}

Analysis is an attempt to systematically search and organize the notes of interviews and others to improve the writer's understanding of the case under study and to present it as a finding for others (Kusdiyanto, 2010).

The data obtained is qualitative data and will be analyzed by evaluative methods. This research is using inductive descriptive approach, by which the method of collecting data aims to determine whether the objectives of implementing activities are in accordance with the objectives set. In this case the researcher conducted an analysis of the contents of the judge's decision number 1135 / Pdt.g / 2018 / PA.Klt. by using literature relating to the content of the decision namely the DSN-MUI Fatwa. 


\section{ANALYSIS AND DISCUSSION \\ Principal Case No. 1135 / Pdt.G / 2018 / PA.Klt Regarding the Murābahahah Agreement of the Klaten Religious Court}

Based on case number 1135 / Pdt.G / 2018 / PA.Klt in relation to this breach of dispute is a lawsuit between the defendant (Tri Suyatmi) and the plaintiff (Arifin Hidayat, SE). Tri Suyatmi has submitted an application to the BPRS Al Mabrur to buy land, and based on Tri Suyatmi's request the BPRS Al Mabrur agreed, and with this murābahah contract, committed itself to buy, provide and then sell the land to Tri Suyatmi in accordance with the provisions of the murabahah contract. Then the two parties agreed to make and sign this murābahah contract.

Then Tri Suyatmi violated the provisions / broken promises against the agreed murābahah contract, The forms of default were: 1) Did not meet the achievements at all; 2) Meet the achievements but not on time; 3) Fulfills achievements but is not appropriate or wrong.

Tri Suyatmi promised to make installment payments according to the stipulated installment schedule, Tri Suyatmi agreed to make payments according to the installment schedule each month until the contract was due. But in reality Tri Suyatmi does not want to pay the remaining obligations. There was a dispute in carrying out this contract, then the BPRS Al Mabrur tried to settle the meeting. In the event that efforts to resolve differences of opinion through deliberation do not result in a decision agreed by both parties, the BPRS Al Mabrur hereby agrees to appoint and determine and authorize the Klaten Religious Court office to give its decision, that the legal opinion or decision made is final and binding.

Principal case number 1135 / Pdt.G / 2018 / PA.Klt is a default of the murabahah contract of Rp. 20,000,000 with the calculation of the basic price of Rp. 30,800,000 with a profit margin of Rp. $10,080,000$, - the period (period) of the receivables lasts for 36 months, counting from the date of signing the contract which is 12 June 2017 to 12 June 2020.

Based on article 6 of the agreement on the period and method of payment of installments it is mentioned that the article states 
that the defendant promised to make installment payments in accordance with the stipulated repayment schedule and is settled when due. But in reality, the defendant did not carry out this obligation and until now, the defendant's installment payments have been delayed.

As a result of the breach of contract, the consequence follows in accordance with the Murabahah Financing Agreement Number 2414 / APJBM / AL MABRUR / VI / 2017, with the breakdown of July 2018 as follows:

$\begin{array}{lllr}\text { The remaining principal } & : & \mathrm{Rp} & 17,222,220 \\ \text { Profit } & : & \mathrm{Rp} & 8,680,000 \\ \text { Late Fee } & : & \mathrm{Rp} & 367,644 \\ \text { Auction fee } & : & & 10,000,000 \\ \text { Total Cost } & : & & 36,269,864\end{array}$

Defendants always buy time in installment payments. The plaintiff has collected the defendant's billing related to the late installment payment but the defendant always avoided and was difficult to find. then from the plaintiff's party has sent several warning letters and provided an opportunity for the defendant's party, but until this lawsuit was filed the defendant's party could not complete its obligations to the plaintiff's party.

To guarantee the claim, the plaintiff requested the Head of the Klaten Religion Court to agree to impose a Confiscated Seizure of the defendant's permanent property which was placed by the Klaten Religious Court in the form of SHM land No. 01979 No. Measurement Letter 00297 / Jogosetran / 2016, dated 28/09/2016 Area $167 \mathrm{~m} 2$ with Tri Suyatmi located in Jogosetran, Jogosetran, Kalikotes, Klaten which has been bound by binding the Deed of Imposing Rights (APHT) with a Certificate of Mortgage Number: 2895 / 2018 with the mortgage rights holders on behalf of PT. BPRS AL MABRUR KLATEN.

The Plaintiff has made various billing efforts, to warn but the defendant still has no good intention to settle his obligations until now, therefore it is very reasonable for the plaintiff to submit a Sharia Economic Dispute Lawsuit, to the Chairperson of the 
Klaten Religious Court this matter is in accordance with the provisions of Article 49 letter (i) Law No.3 of 2006 concerning Amendments to Law Number 7 of 1989 concerning Religious Courts no. Article 55 paragraph (1) of Law No. 21 of 2008 concerning Islamic Banking.

On the day of the trial that has been set for that, the Plaintiff, namely the Managing Director of PT Syariah Islamic Boarding Bank al Mabrur Klaten, was present at the hearing, so Defendant 1 and Defendant 2 were present personally at the hearing.

Whereas, the Examining Judge has tried to reconcile the plaintiff and the defendant, but to no avail, then the plaintiff's claim was read out, the contents of which were retained by the plaintiff. Based on the plaintiff's claim, the defendant has submitted an answer, which is basically "according to the defendant, everything that was stated by the plaintiff in the lawsuit is entirely true". Basically the defendant wants to settle the obligation, but the defendant is unable to, unless restructured and given grace. The settlement time is 10 months, while the plaintiff is no longer willing to restructure the debt, because so far the plaintiff has done so and the Plaintiff still wants the defendant to settle the obligations in accordance with the given deadline.

\section{Judge's Considerations in Case Decision number 1135 / Pdt.g /2018/PA.Klt}

In deciding the Islamic economic dispute case number 1135 / Pdt.G / 2018 / PA.Klt The Judge of the Klaten Religious Court has several considerations in deciding the case, among others as follows:

1. That according to the provisions of Article $130 \mathrm{HIR}$ (Herziene Indonesisch Reglement), "The examining judge has tried to reconcile the litigants", but to no avail.

2. That before considering the principal claim of the Plaintiff, the Examining Judge will first consider the authority of the Klaten Religious Court to hear the Aquo case and the Plaintiff's legal standing to file the Aquo case.

3. That based on the provisions of Article 49 of Law Number 3 of 2006 concerning Religious Courts as an amendment to the 
Law No. 7 of 1989 states, the religious court has the duty and authority to examine, decide upon, and settle cases at the first level among people who are Muslims in field of marriage, inheritance, wills, grants, endowments, zakat, infaq, sadaqah and Sharia economy (which includes Sharia banking).

4. That what is meant by "Sharia economy" is an action or business activity carried out according to Sharia principles, including but not limited to: Sharia banks, Sharia micro financial institutions, Shari'ah insurance, Sharia reinsurance, funds retirement of Shari'a financial institutions, Shari'ah business, Shariah mutual funds, Sharia bonds and Shari'ah mid-term securities, Shari'ah securities, Sharia financing, and Sharia pawnshops.

5. That in accordance to the provisions of the Supreme Court Regulations R.I. Number 14 of 2016 concerning Procedures for Settlement of Sharia Economic Cases, the Court which has the authority to make decisions is a court within the religious court environment, and the Judge is the first level judge in a religious court environment that has been certified by a Sharia economic judge.

6. That because this case is included in Shari'ah economic disputes and "Simple Lawsuit" as stipulated in Supreme Court Regulation number 14 of 2016 concerning Sharia economic dispute settlement, the procedure for submission, examination, verification, decision and / or procedural law over the Aquo case follows the provisions of Supreme Court Regulation Number 2 of 2015 concerning Simple Procedure Settlement Procedures.

7. That based on evidence P.1, up to P.5, namely:

P.1 Photocopy of financing agreement Number 2414/ APJBM/AL MABRUR/ VI/2017

P.2 Photocopy of certificate of ownership Number 01979 No. Letter of Measurement 00297/ Jogosetran/ 2016, Dated 28/09/2016 as wide as $167 \mathrm{~m}^{2}$ a.n Tri Suwarni located in Jogosetran, Jogosetran, Kalikotes, Klaten

P.3 Photocopy of old age benefit number 2895/2018

P.4 Financing history report of customer (Tri Suyatmi) up to Rp. 20.000.000,- 
P.5 Photocopy of Warning letters:

- P.5.a Letter of notification N : REM.188/SP/AL MABRUR/XII/2017

- P.5.b First Warning letter No : REM.004/SP1/ AL MABRUR/I/2018

- P.5.c Second Warning letter No : REM.028/SP2/ AL MABRUR/II/2018

- P.5.d Third Warning letter No : REM.049/SP3/ AL MABRUR/III/2018

- P.5.e Invitation Letter No : REM.097/SPg/AL MABRUR/VI/2018.

It is proven that this case is a dispute of "Sharia economy" which is categorized as a "Simple Lawsuit" or small claim court, and the Plaintiffs and Defendants themselves want this case being examined and decided by the Religious Court. Therefore, the Klaten Religious Court has the authority to examine and try and resolve this case.

8. That based on P.7 and P.8, namely:

P.7 Photocopy of Deed of Extraordinary General Meeting of Shareholders' Statement of the BPRS Al Mabrur Klaten, Number 4 dated 19 August 2014

P.8 Photocopy of Deed of Extraordinary General Meeting of Shareholders' Statement of the BPRS Al Mabrur Klaten, Number 8 dated March 22, 2016.

Stating that the plaintiff is the main director of the BPRS Al Mabrur which carryies out its business activities based on Sharia principles, and the plaintiff is as a creditor and or sahibul maal, while something in question with regard to the defendant as a debtor or mudharib is the non-compliance of the defendant in fulfilling his obligations upon the contract made or breach of contract. Then according to the Examining Judge, the Plaintiff has a legal standing as a party in the Aquo case. 
9. That the basis for the Aquo Plaintiff's claim and argument is the fact that there have been 3 (three) funding agreements based on Sharia principles between the plaintiff and the defendant, namely: The contract was made on June 12, 2017 with the contract number: 2414 / APJBM / AL MABRUR / VI / 2017, the defendant himself unanimously acknowledged the trial. However, the defendant has been in breach of contract by failing to carry out his obligations, so that the plaintiff has suffered a principal and margin loss or profit sharing that must be received in the amount of Rp. 25,902,220 (twenty five million nine hundred and two thousand two hundred twenty two rupiah).

10. That on the argument of the plaintiff, the defendant confirmed and acknowledged unanimously about the existence of a murabaha financing agreement as described in the plaintiff's claim, however the defendant no longer has the ability to repay these obligations and the plaintiff and defendant agreed to be resolved and decided by the Klaten Religious Court.

11. That the plaintiff has submitted evidences P.1, P.2, dan P.3:

P.1 Photocopy of financing contract No. 2414/APJBM/AL MABRUR/ VI/2017;

P.2 Photocopy of certificate of ownership Number 01979 No. Letter of Measurement 00297/ Jogosetran/ 2016, Dated 28/09/2016 as wide as $167 \mathrm{~m} 2$ a.n Tri Suwarni located in Jogosetran, Jogosetran, Kalikotes, Klaten

P.3 Photocopy of old age benefit number 2895/2018

The evidence is an authentic deed and there is no objection to the evidence, so based on the provisions of Article $165 \mathrm{HIR}$, the evidence has the strength of proof (voilledig) and binding (bindende). Therefore, it must be proven that between the Plaintiff and Defendant there has been an agreement of Murabahah Financing with a guarantee in the form of SHM Number 1659 and SHM Number 1660.

12. That based on evidence P.4, namely, payment history, it is validly proven that the principal of the defendant's loan to the plaintiff is as follows: 


\begin{tabular}{ccccc}
\hline \multicolumn{2}{c}{ Value (Rp) } & $\begin{array}{c}\text { Total profit } \\
(\mathbf{R p})\end{array}$ & $\begin{array}{c}\text { Principal and } \\
\text { Profit (Rp) }\end{array}$ & Time Period \\
\hline Initial value & $20,000,000$ & $10,080,000$ & $30,080,000$ & 36 \\
Paid & $2,777,780$ & $1,400,000$ & $4,177,780$ & 5 \\
Not Paid & $17,222,220$ & $8,680,000$ & $25,902,220$ & 31 \\
\hline
\end{tabular}

Based on the plaintiff's explanation, it is stated that murabaha financing that must be paid by Tri Suyatmi is Rp.30,080,000, with a period of (receivable) period that lasts for 36 months, starting from the signing date of the contract, which is 12 June 2017 to 12 June 2020, and has been paid in the amount of Rp.4,177,780, - as for the remaining unpaid liabilities of Rp. 25,902,220,-

13. That based on evidences P.5.a, P.5.b, P.5.c, P.5.d, and P.5.e that follow:

P.5.a Notification Letter No : REM.188/SP/AL MABRUR/ $\mathrm{XII} / 2017$

P.5.b First warning letter No : REM.004/SP1/AL MABRUR/I/2018

P.5.c Second warning letter No : REM.028/SP2/AL MABRUR/II/2018

P.5.d Third warning letter No : REM.049/SP3/AL MABRUR/III/2018

P.5.e Invitation Letter No : REM.097/SPg/AL MABRUR/ $\mathrm{VI} / 2018$.

it is proven that the plaintiff has notified the maturity of the defendant's debt obligations, and has been given a reprimand, but is not heeded, even tends to let and has ignored the reprimand without any good intention to resolve it.

14. That default in Dutch means "bad achievement". What is meant by the term default in the other words is a condition caused by negligence or mistake, the debtor cannot fulfill the specified agreement and is not in a forced condition. Considering, that from the results of the Examining Judge's examination of the evidence submitted by the plaintiff, the following legal facts were obtained : 
- That it is proven that the defendant has not fulfilled the obligations (achievements) of the plaintiffs as stated in the contract of murabaha financing agreement Article 6 paragraph 1 of the murabaha Agreement Number 2414 / APJBM / AL MABRUR / VI / 2017 signed on June 12, 2017.

- That it is evident that the plaintiff has notified the obligations to the plaintiff, as in Exhibit P.6 in the form of a photocopy of the Plaintiff's ID card, but the defendant tends to leave without any good intention to resolve it.

15. That with respect to this promise or breach of contract, in accordance with Article 1243 of the Civil Code, which has been strengthened by the jurisprudence of the Supreme Court No. 186 K / Sip / 1959 dated July 1, 1959, the "Engagement is intended to give something, to do something, or not to do something" or if it turns out in the agreement there is a clause stating that the debtor is considered negligent without requiring a summons (summon) or warning.

16. That the calculation of compensation on defaults is calculated from the moment of negligence, in accordance with Article 1237 of the Civil Code, "On an agreement to provide certain goods, the goods are the responsibility of the creditor since the engagement was born. If the debtor fails to surrender the item in question, then the item, since the engagement was made, become his responsibility".

17. That based on the aforementioned facts, it must be legally proven that the defendant "has not fulfilled the promised achievement and or has broken the promise (default)", so that the defendant's actions have harmed the plaintiff as a "creditor", where the plaintiff himself as the creditor must bear the responsibility answer to its customers. Therefore all negligence committed by the defendant against the Plaintiff must be calculated as negligence that contains a real loss..

18. That "profit sharing" is a form of alternative financing scheme, which has very different characteristics compared to interest-based financing scheme. In reality, this scheme is in 
the form of sharing of the results of operations financed, in the form of direct financing or financing through Islamic banks (in the form of mudhārabah and musyārakah financing). Based on profit sharing aggrement, it is necessary to design an optimal profit sharing scheme, in the form of an efficient way to encourage entrepreneurs (debtors) to make their best efforts and can reduce the occurrence of falsification.

19. That what underly the financing agreement between the plaintiff and the defendant is "profit sharing" (sometimes also called profit-and-loss sharing. Wat is used as the basis for calculation is profit, which is the spread between business income and business costs, both in the form of cost of goods sales, production costs, sales costs, and general and administrative costs or in other terms profit sharing can be interpreted as a system of profit sharing derived from a business.

20. That based on the aforementioned facts, the Examining Judge is of the opinion that because the defendant has been proven to have defaulted on the plaintiff, the defendant was sentenced to return the loan principal and the profit share that should have been received by the plaintiff totaling Rp. 25,902,220, - (twenty-five million, nine hundred and two thousand, two hundred twenty rupiahs).

21. That with regard to the demand for a "late fee", this is a real loss of the creditor due to non-operation of the money circulating in the bank, while has been promised. Because such matter is considered to be grounded and reasonable, an amount of Rp. 367,644 can be granted (three hundred sixty seven thousand, six hundred forty four rupiah).

22. That while claims for auction costs amounting to Rp.10,000,000 (ten million rupiah), in principle because the auction is a real and measurable loss suffered by the plaintiff due to the defendant's actions, then the claim according to the examining judge has sufficient reasons and the claim can be granted

23. That based on the aforementioned considerations, the claim of the plaintiff may be granted and rejects other than the rest. 
24. That because the defendant was on the losing side, it was in accordance with the provisions of Article 181 paragraph (1) HIR,

The defendant is charged to pay all the costs of this case.

\section{Analysis on the Conformity of the Klaten Religious Court's Verdict with DSN-MUI Fatwa}

In the following, the author tries to analyze the verdict regarding the case of default of the murabaha contract as stated in the Klaten religious court decision on case number 1135 / Pdt.g / 2018 / PA.Klt.

1. Based on the legal aspects handed down by the judge, stating that the actions of Tri Suyatmi committed breach of promise to the plaintiff, the defendant promised to make installment payments in accordance with the stipulated repayment schedule and paid at maturity. But in reality, the defendant did not carry out this obligation. Defendants always buy time in installment payments. The plaintiff has collected the defendant's billing related to late installment payments but the defendant has always avoided and is difficult to be contacted. In addition to that, the plaintiff's party has sent several warning letters and provided an opportunity for the defendant's party, but until this lawsuit was filed the defendant's party could not complete its obligations to the plaintiff's party.

In terms of DSN-MUI Fatwa Number 17 / DSN-MUI / IX / 2000 concerning Sanctions on eligible customers who can postpone payment that:

a. Sanctions referred to in this fatwa are sanctions imposed by Sharia-compliant financial institution on customers who can afford to pay, but delay payments on purpose.

b. Customers who are unable to pay due to force majeure may not be subject to sanctions.

c. Capable customers who delay payment and / or do not have the will and good faith to pay their debts may be subject to sanctions. 
Based on what has been explained above with regard to Sanctions on eligible customers, the judge's decision is correct procedurally and in accordance with DSN-MUI Fatwa Number. 17 / DSN-MUI / IX / 2000.

2. Based on the legal aspects imposed, the Judge decides that the defendant pays all remaining obligations to the plaintiff in the form of:

a. The principal debt as well as some margin of Rp. 25,902,220,-

b. An amount of late cost of Rp. 367.644,-

c. Maintenance and auction fees that amount Rp. 10.000.000,-

In terms of DSN-MUI Fatwa No. 43 / DSN-MUI / II / 2004 concerning Compensation ( $T a$ 'wi '):

1) Compensation (ta'wiḍ) may only be imposed on the party who intentionally or because of negligence to do something that deviates from the terms of the contract and causes harm to other parties.

2) Real losses that can be calculated clearly, in the form of real costs incurred in the context of collection of rights that should be paid.

3) Promised parties are responsible for case costs and other costs arising from the case resolution process.

Based on what has been explained above with regard to compensation, the judge's decision is correct procedurally and in accordance with DSN-MUI Fatwa No. 43 / DSN-MUI / IX / 2004.

3. To punish the defendant to voluntarily sell collateral objects or to hand over collateral objects to the plaintiff for sale, otherwise the sale is made by force through a public auction process to the Surakarta State Wealth and Auction Services Office (KPKNL), if the defendant cannot pay all the rest the plaintiff's obligation a number that has been described in the decision number 2 above. 
Judging from the procedure of confiscation and DSN-MUI Fatwa No. 47 / DSN-MUI / II / 2005 concerning Settlement of Murabaha Receivables for Customers Unable to Pay:

a. The Procedure of Confiscation

1) Confiscation can only be carried out on the basis of a court ruling

2) Confiscation is carried out by a bailiff or clerk based on the assignment letter designated in the stipulation letter

3) The notice of confiscation must have been informed to the confiscated respondent or defendant

4) The bailiff was assisted by two witnesses

5) The confiscation was stated in the official report of confiscation.

6) Seizure registration, confiscation minutes are registered and announced at the authorized registration office.

7) Declares confiscation to be legal and valuable

b. DSN-MUI Fatwa No. 47 / DSN-MUI / II / 2005 concerning Settlement of Murabaha Receivables for Customers not afford to Pay:

1) Murabaha objects or other collateral are sold by the customer to or through the Sharia-compliant financial institution at an agreed market price

2) The customer repays the remaining debt to the Sharia-compliant financial institution from the proceeds of the sale

3) If the sales proceeds exceed the remaining debt, the Sharia-compliant financial institution returns the remainder to the customer;

4) If the sale proceeds less than the remaining debt, the remaining debt remains the customer's debt.

Based on what has been explained above with regard to Settlement of Murabaha Receivables for Customers not afford to Pay, the judge's decision is correct procedurally and in accordance with DSN-MUI Fatwa No. 47 / DSN- 
MUI / II / 2005.

4. To punish the defendant to pay the entire cost of the case until the verdict is pronounced in the amount of Rp. 401,000,-

According to the author, the judge's decision used is procedurally appropriate. In setting the decision, the Panel of Judges also included the legal basis for the Civil Code (KUHP) to strengthen the referral and outcome of the decision. In the legal basis of the panel of judges, the DSN-MUI Fatwa is not listed. It is therefore preferable that before the Panel of Judges uses the Civil Code, the Panel of Judges should first use the references issued by the Indonesian Ulema Council.

For the Religious Courts, references issued by the DSNMUI Fatwa are very important to include. Because Judges of the Religious Courts in settling Islamic economic cases are required to refer to the provisions of Islamic economic law in force in Indonesia, both in the form of legislation specifically discussing sharia economics and fatwa issued by MUI institutions.

Based on the above analysis, it can be concluded that the legal basis used by the Panel of Judges in determining decision No. 1135 / Pdt.g / 2018 / PA.Klt is in accordance with Islamic Economic Law, namely using the Fatwa of the Sharia Council of the Indonesian Ulema Council (DSN-MUI) concerning the contract Murabaha. In setting the decision, the Panel of Judges also listed the legal basis of the Civil Code (KUHP) to strengthen the reference and outcome of the decision.

\section{CLOSING}

\section{Conclusion}

Based on the analysis of the case of Islamic economic resolution Number. 1135 / Pdt.G / 2018 / PA.Klt with the discussion in the previous chapter, the author concludes several things as follows:

1. The Panel of Judges decided by, 1) declaring the Defendant who had been legally called and deserved to appear before the court, but the defendant was no longer present, 2) granting 
the Plaintiff's claim, Stating that it was legally valid Akad Murābahahah Number 2414 / APJBM / AL MABRUR / VI / 2017 dated June 12, 2017 which was made and signed by the plaintiff with the defendant, 3) Stating that the defendant has broken promise to the murābahah contract Number 2414 / APJBM / AL MABRUR / VI / 2017 dated June 12, 2017, which harmed the plaintiff in the form of material loss of Rp. 36,269,864, - (thirty six million two hundred sixty nine thousand eight hundred sixty four rupiah), 4.) sentencing the defendant to pay damages of Rp. 36. 269,864, - (thirty six million two hundred sixty nine thousand eight hundred sixty four rupiah) to the plaintiff, 5) sentencing the defendant to pay for this whole case, which until now has been calculated as Rp. 401,000 (four hundred and one thousand rupiah).

2. The results of the analysis over the resolution of the Klaten Religious Court Judge Panel in deciding case number 1135 / Pdt.g / 2018 / PA.Klt. shows that the legal basis used by the Panel of Judges in determining decision No. 1135 / Pdt.g / 2018 / PA.Klt is in accordance with Islamic Economic Law, namely using the Fatwa of the Sharia Council of the Indonesian Ulema Council (DSN-MUI) concerning the Murābahah contract. In setting the decision, the Panel of Judges also listed the legal basis of the Civil Code (KUHP) to strengthen the reference and outcome of the decision.

\section{Suggestion}

To the Klaten Religious Court, it should further improve Islamic economic services, that the resolution of Islamic economic disputes is good. The achievement should be maintained or even more enhanced. As for society in general, the Customer / Community should resolve the problem of dispute at the institution concerned. However, if the relevant institution cannot resolve the problem then it should be resolved at a more competent institution, namely the Religious Courts. 


\section{REFERENCE}

Law Number 21 Year 2008 concerning Sharia Banking.

National Sharia Council, National Sharia Council Fatwa No. 07 / DSN-MUI / VI / 2000, 2000.

National Sharia Council, National Sharia Council No. 43/DSNMUI/VI/2004, 2004.

Prabowo, Bagya Agung. 2012. Aspek Hukum Pembiayaan Murabahah pada Perbankan Syariah. Yogyakarta: UII Press.

Azwar, Saifuddin. 2007. Metode Penelitian. Yogyakarta: Pustaka Pelajar.

Hadi, Sutrisno. 2007. Metodologi Research. Yogyakarta: Andi.

Harahap, M. Yahya, 2012, Hukum Acara Perdata, Jakarta: Sinar Grafika.

Kusdiyanto, 2010. Metodologi Penelitian. Bandung: Universitas Pendidikan Indonesia, Buku Pegangan Kuliah.

Muhammad. 2005. Manajemen Bank Syariah, Yogyakarta: Ekonisia.

Pramono, Nindyo. 2008. Hukum Komersil, Jakarta: Pusat Penerbitan UT.

Rasyid, Roihan A. 2007. Hukum Acara Peradilan Agama. Jakarta: Rajawali Pers.

Satrio, J. 1992, Hukum Perjanjian (Perjanjian Pada Umumnya, Bandung, Citra Aditya Bakti

Subekti. 2002. Hukum Perjanjian. Jakarta: Intermasa.

Supardi. 2005. Metodologi Penelitian Ekonomi dan Bisnis, Yogyakarta: UII Press.

Sunaryo. 2008. Hukum Lembaga Pembiayaan, Jakarta: Sinar Grafika. 